\title{
TINGKAT KEPUASAN SEKOLAH MITRA TERHADAP KINERJA MAHASISWA PPL PRODI PENJASKESREK FKIP UNTAN TAHUN AJARAN 2015-2016
}

\author{
Andika Triansyah \\ Program Studi Penjaskesrek FKIP Untan Pontianak \\ Email : andi.k.triansyah@gmail.com
}

\begin{abstract}
The purpose of this research was to determine the level of satisfaction the performance of the partner schools force students PPL 2012 Penjaskesrek FKIP Untan. The method used in this research was quantitative descriptive method. Engineering samples used in this study using total sampling so the sample amounted to 53 people. The results of the data analysis related to all aspects of the teacher's competency showed that the level of satisfaction the performance of the partner schools force students PPL Penjaskesrek FKIP Untan odd semester 2015/2016 is in Good category (B). Meanwhile, from the assessment of competencies prospective teachers required, namely: (1) Social Competence is in the Very Good category; (2) Personality Competence is in the Very Good category; (3) Professional Competence is in the Good category; and (4) Pedagogic Competence is in the Good category.
\end{abstract}

Keywords : Level of Satisfaction, Performance, Students PPL

\section{PENDAHULUAN}

Praktik Pengalaman Lapangan (PPL) merupakan kegiatan dilaksanakan oleh mahasiswa mencakup latihan mengajar maupun tugas-tugas kependidikan di luar mengajar secara terbimbing untuk memenuhi persyaratan pembentukan profesi pendidik dan kependidikan. Oleh karena itu PPL yang terdapat didalam kurikulum program studi pendidikan jasmani, kesehatan dan rekreasi (penjaskesrek) merupakan program wajib bagi mahasiswa dalam memenuhi tuntutan perkuliahan. Program ini bertujuan untuk membentuk dan membina kompetensikompetensi yang harus dimiliki oleh calon guru. Sasaran yang ingin dicapai adalah kepribadian calon pendidik yang memiliki seperangkat pengetahuan, keterampilan, nilai dan sikap, serta pola tingkah laku yang diperlukan bagi profesinya serta cakap dan tepat menggunakannya didalam menyelenggarakan pendidikan dan pengajaran, baik di sekolah maupun di luar sekolah (Oemar Hamalik, 2009: 171-172).

Undang-Undang No.14 Tahun 2005 tentang Guru dan Dosen, pada Bab IV pasal 10 dan dalam Peraturan Pemerintah No.19 Tahun 2005 tentang Standar Nasional Pendidikan, pada Bab VI pasal 3 ditegaskan bahwa kompetensi pendidik dan tenaga kependidikan. Kompetensi tersebut meliputi: (1) kompetensi pedagogik. (2) kompetensi kepribadian, (3) kompetensi profesional, dan (4) kompetensi sosial. Mahasiswa penjaskesrek yang nantinya akan menjadi guru harus mendapatkan bekal yang memadai agar dapat menguasai sejumlah kompetensi yang diharapkan tersebut, baik melalui preservice training maupun inservice training. Salah satu bentuk presrvice training calon guru tersebut adalah melalui pembentukan kemampuan dasar mengajar (teachingskill) baik secara teoritis maupun praktis. Secara praktis, bekal kemampuan mengajar dapat dilatihkan melalui kegiatan microteaching atau pengajaran mikro yang kemudian dilanjutkan dengan program PPL.

Pengajaran mikro merupakan pelatihan tahap awal dalam pembentukan kompetensi mengajar melalui pengaktualisasian kompetensi dasar mengajar. Pengajaran mikro adalah pengajaran di mana menempatkan guru dalam suatu lingkungan kelas 17 simulasi, dimana guru mengajar satu konsep atau satu keterampilan saja, menggunakan satu keterampilan mengajar dan siswa dalam jumlah kecil serta dalam waktu yang pendek (Oemar Hamalik, 2009: 151). Dalam 
pengajaran mikro, mahasiswa dapat berlatih unjuk kompetensi dasar mengajar secara terbatas dan secara terpadu dari beberapa kompetensi dasar mengajar, dengan kompetensi materi, peserta didik, maupun waktu yang dipresentasikan dibatasi (dimikrokan). Pengajaran mikro memiliki implikasi yang cukup luas, baik terhadap ilmu kependidikan sendiri, maupun terhadap profesi guru dan system pendidikan guru, dan telah dirintis penggunaannya pada beberapa lembaga pendidikan.

Unit PPL FKIP Untan yang merupakan lembaga penyelenggara telah bekerja sama dengan sekolah mitra yang nantinya akan ditempati oleh mahasiswa PPL, termasuklah mahasiswa prodi penjaskesrek semester ganjil tahun 2015/2016. Penempatan mahasiswa PPL yang telah dikordinasi dengan sekolah mitra telah berlangsung lama sehingga kerjasama yang telah lama ada ini harus dijaga. Salah satu cara menjaganya adalah dengan mempersiapkan mahasiswa yang akan PPL sebaik mungkin, selanjutkan sekolah mitra yang ditunjuk akan ikut berkontribusi mendidik mahasiswa PPL dengan memberikan pendampingan guru pamong pada masing-masing mahasiswa sesuai dengan bidang keahlian guru.

Dengan status sebagai mahasiswa sudah tentu kemampuan mahasiswa dalam mengajar maupun melaksanakan kewajiban-kewajiban sebagai calon guru disekolah mitra belum maksimal, hal tersebut perlu diketahui lebih jauh tentang penilaian sekolah mitra yang akan diwakilkan oleh guru pamong terhadap kinerja mahasiswa program studi penjaskesrek selama melaksanakan program PPL, sehingga penilaian tersebut dapat menjadi masukan bagi lembaga khususnya prodi penjaskesrek dalam mempersiapkan lulusan maupun memperbaiki capaian pembelajaran yang diperlukan sesuai kebutuhan stakeholder.

Berdasarkan penjelasan di atas, penulis tertarik untuk untuk mengetahui tingkat kepuasan sekolah mitra terhadap kinerja mahasiswa PPL angkatan 2012 Prodi Penjaskesrek FKIP Untan. Masalah umum dalam penelitian ini adalah Bagaimana tingkat kepuasan sekolah mitra terhadap kinerja mahasiswa PPL angkatan 2012 Prodi Penjaskesrek FKIP Untan?

\section{METODE}

Metode yang digunakan adalah metode deskriptif kuantitatif dengan bentuk penelitian survei.Populasi dalampenelitian iniadalah sekolah mitra yang diwakili oleh guru pamong mahasiswa PPL Penjaskesrek FKIP Untan yang berjumlah 53 orang. Teknik sample yang digunakan yaitu total sampling sehingga jumlah sampel yang ada berdasarkan jumlah populasi yaitu 53 orang. Teknik pengumpulan data yang digunakan dalam penelitian ini menggunakan angket tertutup. Untuk mengukur variabel penelitian pada angket menggunakan skala likert. Adapun indikator yang digunakan sebagai berikut: (1) Sangat baik $=4$, (2) Baik = 3, (3) Kurang= 2, (4) Sangat Kurang= 1. Uji validitas dan realibilitas instrument pada penelitian ini menggunakan instrument penilaian kinerja mahasiswa dari Unit PPL FKIP Untan.

\section{HASIL DAN PEMBAHASAN \\ Hasil Penelitian}

Secara sistematis penyajian data dalam penelitian ini diperoleh dari 53 angket berdasarkan tanggapan dari guru pendamping (pamong) mahasiswa berkaitan dengan tingkat kepuasan sekolah mitra terhadap kinerja mahasiswa PPL Prodi Penjaskesrek FKIP Untan. Adapun ringkasannya disajikan pada tabel 1 dan grafik 1 berikut ini :

Tabel 1. Tanggapan Guru Pamong Di Sekolah Mitra terhadap Kinerja Mahasiswa PPL

\begin{tabular}{cccccc}
\hline $\begin{array}{c}\text { Tingkat } \\
\text { Kepuasan }\end{array}$ & $\begin{array}{c}\text { Jumlah } \\
\text { responden }\end{array}$ & $\begin{array}{c}\text { Persentase } \\
\text { Responden }\end{array}$ & $\begin{array}{c}\text { Jumlah } \\
\text { Nilai }\end{array}$ & $\begin{array}{c}\text { Rata-rata } \\
\text { Nilai }\end{array}$ & Kategori \\
\cline { 1 - 3 } S. Baik & 22 & $41 \%$ & 179 & 3.4 & Baik \\
\cline { 1 - 3 } Baik & 29 & $55 \%$ & & \\
\cline { 1 - 3 } Kurang & 2 & $4 \%$ & & \\
\cline { 1 - 3 } S. Kurang & 0 & $0 \%$ & & \\
& 53 & $100 \%$ & & \\
\end{tabular}




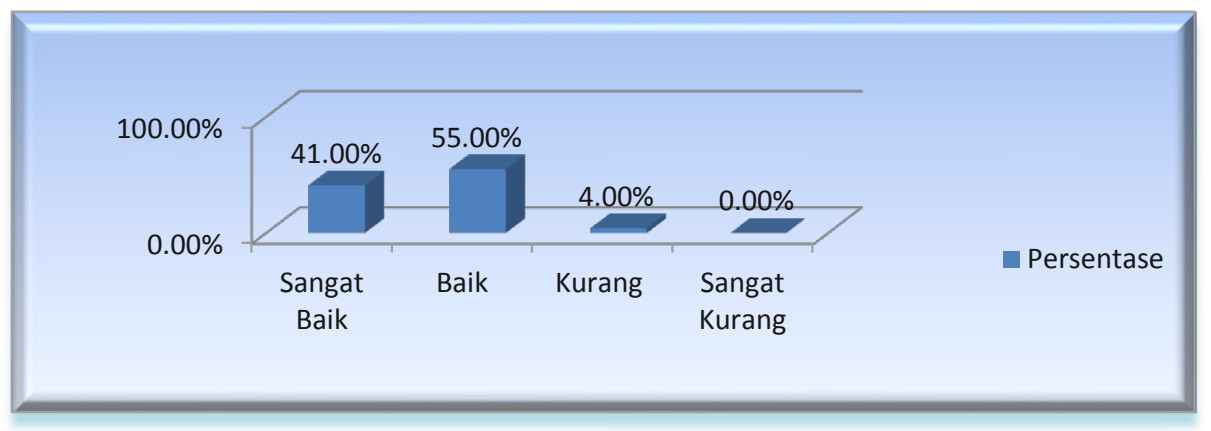

Diagram 1. Tanggapan Guru Pamong Di Sekolah Mitra

Berdasarkan tabel 1 dan grafik 1 tersebut menunjukkan bahwa tingkat kepuasan sekolah mitra yang diwakili oleh guru pamong terhadap kinerja mahasiswa PPL Prodi Penjaskesrek FKIP Untan secara keseluruhan tergolong 4 kategori tingkat penilaian yaitu sangat baik sebanyak 22 orang atau sebesar $41 \%$, kategori baik sebanyak
29 orang atau sebesar $55 \%$, kategori kurang sebanyak 2 orang atau sebesar $4 \%$, dan kategori sangat kurang sebanyak 0 orang atau sebesar $0 \%$.

Selanjutnya diskripsi hasil penilaian yang diperoleh berdasarkan kompetensi yang harus dimiliki seorang calon guru. Adapun ringkasannya disajikan pada tabel 2 dan grafik 2 berikut ini :

Tabel 2. Penilaian Berdasarkan Kompetensi yang Harus Dimiliki oleh Calon Guru

\begin{tabular}{|c|c|c|c|c|c|c|}
\hline $\begin{array}{c}\text { Kompetensi } \\
\text { Guru }\end{array}$ & $\begin{array}{c}\text { Tingkat } \\
\text { Kepuasan }\end{array}$ & $\begin{array}{c}\text { Jumlah } \\
\text { Responden }\end{array}$ & $\begin{array}{l}\text { Persentase } \\
\text { Responden }\end{array}$ & $\begin{array}{c}\text { Jumlah } \\
\text { Nilai }\end{array}$ & $\begin{array}{c}\text { Rata-rata } \\
\text { Nilai }\end{array}$ & Kategori \\
\hline \multirow[t]{4}{*}{ Sosial } & S.Baik & 34 & $64 \%$ & 191 & 3.6 & SB \\
\hline & Baik & 17 & $32 \%$ & & & \\
\hline & Kurang & 2 & $4 \%$ & & & \\
\hline & S.Kurang & 0 & $0 \%$ & & & \\
\hline \multirow[t]{4}{*}{ Kepribadian } & S. Baik & 29 & $55 \%$ & 186 & 3.5 & SB \\
\hline & Baik & 22 & $41 \%$ & & & \\
\hline & Kurang & 2 & $4 \%$ & & & \\
\hline & S.Kurang & 0 & $0 \%$ & & & \\
\hline \multirow[t]{4}{*}{ Profesional } & S.Baik & 10 & $19 \%$ & 166 & 3.1 & $\mathrm{~B}$ \\
\hline & Baik & 40 & $75 \%$ & & & \\
\hline & Kurang & 3 & $6 \%$ & & & \\
\hline & S.Kurang & 0 & $0 \%$ & & & \\
\hline \multirow[t]{4}{*}{ Pedagogik } & S. Baik & 9 & $17 \%$ & 164 & 3.1 & B \\
\hline & Baik & 40 & $75 \%$ & & & \\
\hline & Kurang & 4 & $8 \%$ & & & \\
\hline & S.Kurang & 0 & $0 \%$ & & & \\
\hline
\end{tabular}

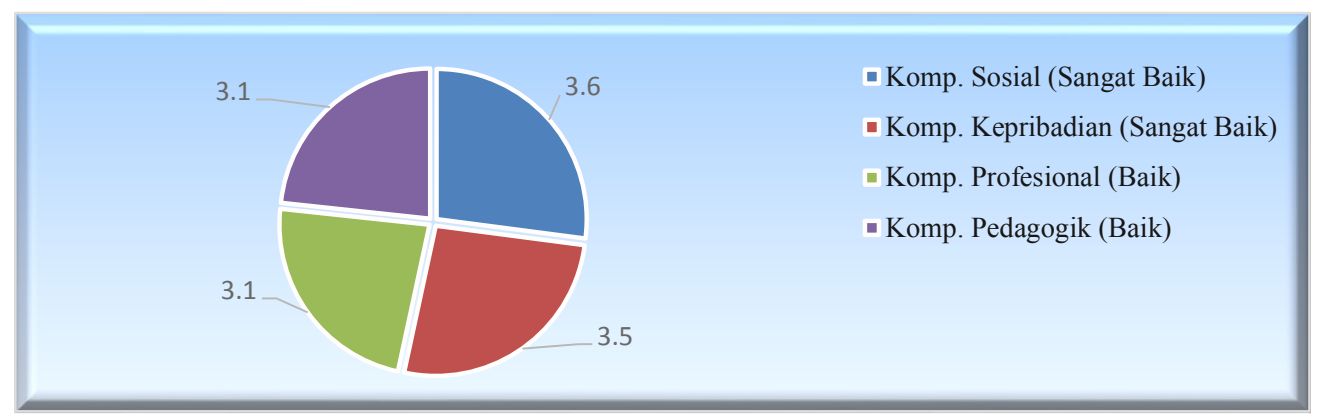

Diagram 2. Tingkat Kepuasan Guru Pamong Di Sekolah Mitra Sesuai Kompetensi Guru 
Berdasarkan tabel 2 dan diagram 2 tersebut menunjukkan bahwa tingkat kepuasan sekolah mitra terhadap kinerja mahasiswa PPL Prodi Penjaskesrek FKIP Untan diperoleh dari setiap aspek kompetensi guru yang meliputi kompetensi sosial, kompetensi kepribadian, kompetensi profesional, dan kompetensi pedagogik.

Kompetensi sosial termasuk kategori sangat baik, hasil diperoleh berdasarkan rata-rata penilaian guru pamong yaitu penilaian sangat baik sebanyak 34 orang atau sebesar $64 \%$, penilaian baik sebanyak 17 orang atau sebesar $32 \%$, penilaian kurang sebanyak 2 orang atau sebesar $4 \%$ dan penilaian sangat kurang sebanyak 0 orang atau sebesar $0 \%$.

Kompetensi kepribadian termasuk kategori sangat baik, hasil diperoleh berdasarkan ratarata penilaian guru pamong yaitu sangat baik sebanyak 29 orang atau sebesar $55 \%$, penilaian baik sebanyak 22 orang atau sebesar $41 \%$, penilaian kurang sebanyak 2 orang atau sebesar $4 \%$ dan penilaian sangat kurang 0 orang atau sebesar $0 \%$.

Kompetensi profesional termasuk kategori baik, hasil diperoleh berdasarkan rata-rata penilaian guru pamong yaitu sangat baik sebanyak 10 orang atau sebesar $19 \%$, penilaian baik sebanyak 40 orang atau sebesar $75 \%$, penilaian kurang sebanyak 3 orang atau sebesar $6 \%$ dan penilaian sangat kurang 0 orang atau sebesar $0 \%$.

Kompetensi pedagogik termasuk kategori baik, hasil diperoleh berdasarkan rata-rata penilaian guru pamong yaitu sangat baik sebanyak 9 orang atau sebesar $17 \%$, penilaian baik 40 orang atau sebesar $75 \%$, penilaian kurang sebanyak 4 orang atau sebesar $8 \%$ dan penilaian sangat kurang 0 orang atau sebesar 0 $\%$.

\section{Pembahasan Penelitian}

Pelaksanaan penelitian dilakukan dengan penyebaran angket, sebelum angket tersebut berada dipihak responden, terlebih dahulu peneliti meminta untuk adanya pertemuan antara peneliti dan mahasiswa yang melaksanakan PPL diwaktu yang sudah ditentukan. Pertemuan tersebut peneliti menjelaskan tujuan dan maksud yang akan dilakukan pada tahapan selanjutnya, yang kemudian angket dibawa oleh mahasiswa PPL bersangkutan untuk diserahkan ke masingmasing guru pamong dengan cara angket dimasukan didalam amplop tertutup yang bersifat rahasia. Angket yang akan diterima oleh responden bersifat angket tertutup, hal itu dimaksudkan untuk mencegah adanya manipulasi yang dapat terjadi.

Penelitian ini dilaksanakan dengan memperoleh tanggapan dari setiap responden. Tanggapan tersebut dapat diuraikan pada lembar angket dengan bentuk yang sudah valid dan reliable yang sudah disediakan oleh peneliti. Responden yang dimaksud ialah guru pendamping (pamong) yang ada di sekolah mitra tempat dimana mahasiswa PPL khususnya Prodi Penjaskesrek FKIP Untan melaksanakan program wajib yang diselenggarakan oleh unit PPL FKIP UNTAN. Jumlah responden yang dipilih sebanyak 53 orang berdasarkan tempat mahasiswa melaksanakan PPL di sekolah mitra. Pada angket tersebut, setiap responden diminta untuk menjawab beberapa pertanyaan yang ada yaitu berjumlah 12 pertanyaan. Angket tersebut mengandung beberapa aspek kompetensi guru meliputi kompetensi sosial, kompetensi kepribadian, kompetensi profesional dan kompetensi pedagogik. Untuk instrument penilaian kinerja mahasiswa pada angket diperoleh dari Unit PPL FKIP Untan.

Adapun hasil dari penelitian ini secara keseluruhan penilaian guru pamong terhadap mahasiswa Prodi Penjaskes FKIP Untan yang telah melaksanakan PPL pada tahun ajaran 2015/2016 termasuk dalam kategori Baik, jika lebih jauh lagi untuk mengetahui penilaian guru pamong terhadap kemampuan mahasiswa PPL Prodi Penjaskes FKIP Untan berdasarkan kompetensi yang harus dimiliki calon guru yaitu: (1) Kompetensi sosial termasuk dalam kategori sangatbaik;(2)Kompetensikepribadiantermasuk 
dalam kategori sangat baik; (3) Kompetensi Profesional termasuk dalam kategori Baik; (4) Kompetensi Pedagogik termasuk dalam kategori Baik. Hasil ini menunjukan bahwa mahasiswa prodi Penjaskes FKIP Untan telah dipersiapkan dengan baik selama proses perkuliahan yang tentunya didukung oleh perangkat pendidikan yang baik seperti tenaga pendidik, kurikulum, fasilitas dan tenaga kependidikan.

Dalam kurikulum Prodi Penjaskes FKIP Untan, sebelum mahasiswa melaksanakan PPL mahasiswa terlebih dahulu harus lulus Microteaching dimana pada tahapan ini mahasiswa dipersiapkan untuk praktek langsung dalam skala kecil atau dengan kata lain dikondisikan praktek mengajar lengkap dengan perangkat pengajaran yang harus dipersiapkan dan proses belajar mengajar (PBM) yang telah direncanakan ditambah pada tahapan ini mahasiswa akan dibimbing langsung oleh dosen pendamping yang telah ditunjuk oleh Unit PPL FKIP Untan. Faktor yang diungkapkan di atas dapat menjadi penyebab baiknya penilaian guru pamong terhadap kinerja mahasiswa prodi Penjaskesrek FKIP Untan. Hasil ini juga sejalan dengan peningkatan akreditasi Prodi Oleh BAN PT pada tahun 2015 yang menyatakan bahwa akreditasi Prodi Penjaskesrek FKIP Untan termasuk kategori Baik (B).

\section{SIMPULAN DAN SARAN Simpulan}

Berdasarkan hasil dan pembahasan dalam penelitian ini dapat disimpulkan penelitian mengenai tingkat kepuasan sekolah mitra terhadap kinerja mahasiswa PPL Prodi Penjaskesrek FKIP Untan semester ganjil tahun
2015/2016 termasuk dalam kategori baik (B). Sedangkan jika penilaian dilihat dari kompetensi yang harus dimiliki calon guru yaitu: (1) Kompetensi Sosial termasuk dalam kategori Sangat Baik; (2) Kompetensi Kepribadian termasuk dalam kategori Sangat Baik; (3) Kompetensi Profesional termasuk dalam kategori Baik; dan (4) Kemampuan Pedagogik termasuk dalam kategori Baik.

\section{Saran}

Adapun saran yang dapat diberikan dari hasil penelitian ini sebagai berikut: (1) Pertahankan proses pembelajaran mahasiswa yang sudah sangat baik terutama yang berhubungan dengan kompetensi sosial dan kepribadian mahasiswa; (2) Perlu ditingkatkan lagi proses pembelajaran mahasiswa yang sudah baik menjadi sangat baik terutama yang berhubungan dengan kompetensi professional dan pedagogik mahasiswa; (3) Berdasarkan masukan guru pamong sebaiknya mahasiswa yang sedang PPL tidak mengulang mata kuliah, sehingga tidak ada ijin lagi karena hal tersebut pada saat proses PPL berlangsung; (4) Mahasiswa perlu ditingkatkan lagi penguasaan dalam menyajikan materi pembelajaran dan dalam membuat atau memodifikasi media pembelajaran; (5) Perlunya koordinasi antara guru pamong dengan dosen pembimbing PPL selama proses PPL berlangsung.

\section{DAFTAR RUJUKAN}

Hamalik, Oemar. (2009). Pendidikan Guru Berdasarkan Pendekatan Kompetensi. Jakarta: PT Bumi Aksara. (2005). UU RI No 14 Tentang Guru dan Dosen. Bandung: Citra Umbara. 
